\section{'Paulk', a Muscadine Grape with Hermaphroditic Flowers and Large Berries}

\author{
Patrick J. Conner \\ University of Georgia-Tifton Campus, 2360 Rainwater Road, Tifton, GA \\ 31793
}

Additional index words. Vitis rotundifolia, breeding, cultivar, variety, Muscadinia rotundifolia

'Paulk' is a hermaphroditic muscadine grape (Vitis rotundifolia Michx.) with black berries that was released by the University of Georgia (UGA) College of Agriculture and Environmental Sciences. 'Paulk' produces high yields of large-sized berries with excellent taste suitable for the fresh market. 'Paulk' is the first cultivar with hermaphroditic flowers that produces berries of similar size to the largest female cultivars $(\approx 15 \mathrm{~g})$. 'Paulk' produces a high percentage of usable berries with low incidences of berry rot or pedicel scar splitting. 'Paulk' has a midseason harvest date with an average first pick on 20 Aug. in Tifton, GA. 'Paulk' is recommended as a hermaphroditic black muscadine for fresh-market sales.

\section{Origin}

'Paulk' originated in Tifton, GA, from a cross of 'Supreme' by 'Tara' (Fig. 1). 'Supreme' is a female cultivar that produces black berries with exceptional size and firmness (Conner, 2009). 'Tara' is hermaphroditic and produces bronze berries with dry pedicel scars that ripen early in the muscadine harvest season (Conner, 2009; Lane, 1993). The original 'Paulk' vine first fruited in 2008. The vine was selected in 2009 for its large berry size, hermaphroditic flowers, and excellent flavor. Accordingly, it was propagated for further trials as Ga. 6-2-26. The cultivar was named 'Paulk' in honor of Mr. Jacob Paulk, founder of Paulk Vineyards, GA's largest muscadine grower. Mr. Paulk was instrumental in the establishment of the muscadine industry in Georgia.

\section{Methods}

The testing location was Tifton, GA, on an experimental farm (lat. $31^{\circ} 28^{\prime} 39.81^{\prime \prime} \mathrm{N}$, long. 8331'39.61"W). 'Fry', 'Hall', 'Lane', 'Supreme', and 'Tara' vines were included as control cultivars. Four vines of each control cultivar were planted, but one 'Tara' vine was an off-type, so only three 'Tara' vines were evaluated, and eight vines of 'Paulk' were evaluated. Vines were planted in 2010

Received for publication 25 Aug. 2017. Accepted for publication 3 Oct. 2017.

${ }^{1}$ Corresponding author. E-mail: pconner@uga.edu. with a spacing of $3 \mathrm{~m}$ between plants in the row and $4.5 \mathrm{~m}$ between rows in randomized order. Vines were trained to a single wire trellis with two cordons per vine. Drip irrigation was used, and diseases and insects were controlled according to commercial guidelines (Poling et al., 2003).

Vine vigor was calculated by measuring the caliper of the trunk $75 \mathrm{~cm}$ above the ground before budbreak. Vine yields were estimated by harvesting fruit from $1 \mathrm{~m}$ of the interior cordon (cordon most distal to the trellis post) and then multiplying the sample yield by the total cordon length. Vines were harvested in 2012-16 from one to four times depending on the uniformity of ripening, with the first harvest occurring as soon as $\approx 50 \%$ of the berries were ripe. Once the yield was weighed to give the total yield weight, the berries were then sorted. Berries with any visible signs of decay were removed and weighed to calculate percent berry rot. Of the undecayed berries, berries were sorted into those which had pedicel scar splits (large cracks in which the interior flesh was visible), pedicel scar tears (peeling back of the berry epidermis), and dry pedicel scars. Percentage of each of these categories was calculated by dividing the weight of each category by the total weight of all three categories and then multiplying by 100 . Rotted berries and berries with pedicel scar split are commonly removed when commercial growers pack fruit, so percent usable yield was calculated by the formula $100 \times(1-\%$ berry rot $/ 100) \times$ ( $1-\%$ pedicel scar split/100). Ten berries were immediately randomly selected from the usable yield sample and measured for berry weight, diameter, and number of seeds. All ten berries were then crushed together to provide juice to determine percent soluble solids.

Differences between cultivars were determined using one-way analysis of variance with mean separation by Duncan's multiple range test $(P<0.05)$. Percentage data were analyzed after arcsine-square root transformation. Statistical analysis was performed using SigmaPlot 12.3 statistical software (Systat Software, San Jose, CA).

\section{Description and Performance}

Vines of 'Paulk' are hermaphroditic (perfect flowered) and thus 'Paulk' vines do not need a pollenizer. The vines have moderate vigor, similar to 'Lane' and with less caliper growth than the vigorous female cultivar 'Fry' (Table 1). Leaves averaged $61 \mathrm{~mm}$ in length and $88 \mathrm{~mm}$ in width. Lateral canes are drooping and usually grow $1.6 \mathrm{~m}$ or more in a growing season at Tifton, GA. Typical cane diameter is $3-12 \mathrm{~mm}$ and internode length ranges from 5 to $6 \mathrm{~cm}$ (data not shown). Total yield of 'Paulk' was excellent and consistently ranked among the highest yielding cultivars in all years of this trial (Table 2). Percent usable yield and total usable yield were also equal to or better than control cultivars (Table 2). Berries were generally 
Table 1. Vine caliper of 'Paulk' and standard muscadine cultivars after the first 6 years of growth at Tifton, GA, in years 2011-16.

\begin{tabular}{|c|c|c|c|c|c|c|c|}
\hline Cultivar & No. vines & 2011 caliper $(\mathrm{mm})$ & 2012 caliper $(\mathrm{mm})$ & 2013 caliper $(\mathrm{mm})$ & 2014 caliper $(\mathrm{mm})$ & 2015 caliper $(\mathrm{mm})$ & 2016 caliper $(\mathrm{mm})$ \\
\hline Hall & 4 & $7.2 \mathrm{c}$ & $23.9 \mathrm{ab}$ & 33.4 & $36.5 \mathrm{ab}$ & 37.8 & $44.4 \mathrm{a}$ \\
\hline Lane & 4 & $8.4 \mathrm{bc}$ & $22.8 \mathrm{ab}$ & 30.5 & $33.1 \mathrm{~b}$ & 36.8 & $38.2 \mathrm{~b}$ \\
\hline Tara & 3 & $10.6 \mathrm{ab}$ & $26.4 \mathrm{a}$ & 33.3 & $40.7 \mathrm{a}$ & 41.5 & $41.1 \mathrm{ab}$ \\
\hline Significance & & 0.006 & 0.038 & NS & 0.008 & NS & 0.04 \\
\hline
\end{tabular}

${ }^{\mathrm{z}}$ Caliper measured on the trunk $75 \mathrm{~cm}$ aboveground before budbreak. Mean separation within columns by Duncan's multiple range test $P<0.05$.

NS = nonsignifcant.

Table 2. Yield of 'Paulk' and standard muscadine cultivars at Tifton, GA, in the third through seventh years of growth (2012-16).

\begin{tabular}{|c|c|c|c|c|}
\hline Cultivar & No. vines & Total yield $(\mathrm{kg})$ & Usable yield $(\mathrm{kg})^{\mathrm{z}}$ & Percent usable yield \\
\hline \multicolumn{5}{|l|}{ Year 3} \\
\hline Paulk & 8 & 17.3 & $15.3 \mathrm{a}^{\mathrm{y}}$ & $88.7 \mathrm{a}$ \\
\hline Fry & 4 & 11.7 & $7.0 \mathrm{c}$ & $55.9 \mathrm{~d}$ \\
\hline Hall & 4 & 14.6 & $10.3 \mathrm{bc}$ & $74.0 \mathrm{bc}$ \\
\hline Lane & 4 & 12.9 & $8.4 \mathrm{c}$ & $67.2 \mathrm{~cd}$ \\
\hline Supreme & 4 & 12.8 & $10.3 \mathrm{bc}$ & $81.0 \mathrm{ab}$ \\
\hline Tara & 3 & 19.1 & $14.7 \mathrm{ab}$ & $76.7 \mathrm{abc}$ \\
\hline Significance & & NS & $<0.001$ & $<0.001$ \\
\hline \multicolumn{5}{|l|}{ Year 4} \\
\hline Paulk & 8 & $20.6 \mathrm{ab}$ & $19.2 \mathrm{ab}$ & 93.6 \\
\hline Fry & 4 & $8.7 \mathrm{~d}$ & $6.7 \mathrm{~d}$ & 77.7 \\
\hline Hall & 4 & $21.2 \mathrm{ab}$ & $19.5 \mathrm{ab}$ & 92.1 \\
\hline Lane & 4 & $13.5 \mathrm{~cd}$ & $9.6 \mathrm{~cd}$ & 71.3 \\
\hline Supreme & 4 & $25.1 \mathrm{a}$ & $23.0 \mathrm{a}$ & 91.4 \\
\hline Tara & 3 & $16.5 \mathrm{bc}$ & $14.7 \mathrm{bc}$ & 88.5 \\
\hline Significance & & $<0.001$ & $<0.001$ & NS \\
\hline \multicolumn{5}{|l|}{ Year 5} \\
\hline Paulk & 8 & $31.0 \mathrm{a}$ & $28.4 \mathrm{a}$ & $91.7 \mathrm{a}$ \\
\hline Fry & 4 & $13.8 \mathrm{~cd}$ & $11.6 \mathrm{bc}$ & $82.8 \mathrm{bc}$ \\
\hline Hall & 4 & $22.9 \mathrm{~b}$ & $17.7 \mathrm{c}$ & $76.7 \mathrm{c}$ \\
\hline Lane & 4 & $20.2 b c$ & $17.0 \mathrm{bc}$ & $83.6 \mathrm{bc}$ \\
\hline Supreme & 4 & $24.2 \mathrm{~b}$ & $21.4 \mathrm{ab}$ & $88.7 \mathrm{ab}$ \\
\hline Tara & 3 & $24.5 \mathrm{~b}$ & $21.8 \mathrm{ab}$ & $88.9 \mathrm{ab}$ \\
\hline Significance & & $<0.001$ & $<0.001$ & $<0.001$ \\
\hline \multicolumn{5}{|l|}{ Year 6} \\
\hline Paulk & 8 & 34.1 & 28.1 & $84.0 \mathrm{a}$ \\
\hline Fry & 4 & 33.5 & 22.1 & $67.5 \mathrm{~b}$ \\
\hline Hall & 4 & 29.7 & 24.9 & $68.1 \mathrm{~b}$ \\
\hline Lane & 4 & 23.0 & 17.9 & $75.3 \mathrm{ab}$ \\
\hline Supreme & 4 & 28.7 & 21.9 & $83.2 \mathrm{a}$ \\
\hline Tara & 3 & 33.1 & 27.9 & $79.4 \mathrm{ab}$ \\
\hline Significance & & NS & NS & 0.01 \\
\hline \multicolumn{5}{|l|}{ Year 7} \\
\hline Paulk & 8 & 30.7 & 25.6 & $83.3 \mathrm{ab}$ \\
\hline Fry & 4 & 25.9 & 15.5 & $60.0 \mathrm{c}$ \\
\hline Hall & 4 & 24.0 & 20.7 & $85.8 \mathrm{ab}$ \\
\hline Lane & 4 & 19.2 & 15.5 & $80.6 \mathrm{~b}$ \\
\hline Supreme & 4 & 25.3 & 21.0 & $84.5 \mathrm{ab}$ \\
\hline Tara & 3 & 31.1 & 27.4 & 87.9 a \\
\hline Significance & & NS & NS & $<0.001$ \\
\hline \multicolumn{5}{|l|}{ All Years } \\
\hline Paulk & 8 & $26.4 \mathrm{a}$ & $25.3 \mathrm{a}$ & $87.5 \mathrm{a}$ \\
\hline Fry & 4 & $18.6 \mathrm{~b}$ & $14.3 \mathrm{c}$ & $69.6 \mathrm{c}$ \\
\hline Hall & 4 & $22.5 \mathrm{ab}$ & $20.8 \mathrm{~b}$ & $83.6 \mathrm{ab}$ \\
\hline Lane & 4 & $18.0 \mathrm{~b}$ & $15.1 \mathrm{c}$ & $78.3 \mathrm{~b}$ \\
\hline Supreme & 4 & $22.7 \mathrm{ab}$ & $21.7 \mathrm{ab}$ & $86.5 \mathrm{a}$ \\
\hline Tara & 3 & $25.3 \mathrm{a}$ & $23.8 \mathrm{ab}$ & $86.5 \mathrm{a}$ \\
\hline Significance & & 0.003 & $<0.001$ & $<0.001$ \\
\hline
\end{tabular}

${ }^{\mathrm{z}}$ Usable yield is total yield minus weight of rotted berries and berries with pedicel scar splitting.

${ }^{\mathrm{y}}$ Mean separation within columns by Duncan's multiple range test, $P<0.05$.

NS = nonsignifcant.

free from defects with low levels of rot and pedicel scar splitting and tearing (Table 3). Average first harvest of 'Paulk' was 20 Aug. (Table 3), which was similar to 'Supreme' and later than the other control cultivars. In Tifton, 'Supreme' and 'Fry' are midseason cultivars while 'Hall', 'Lane', and 'Tara' are early season cultivars (Conner, 2009, 2013, 2014). Berry size of 'Paulk' was similar to 'Supreme' and larger than all other control cultivars. Seed number per berry and soluble solids content was similar among all cultivars. 'Paulk' berries are attractive (Fig. 2) and have a good flavor. At harvest, berry firmness was similar to 'Supreme' and more firm than 'Fry'. After $10 \mathrm{~d}$ cold storage, berry firmness was less than 'Supreme' and greater than 'Fry' (Table 4).

Symptoms of Pierce's disease [Xylella fastidiosa (Wells et al.)] have not been observed on 'Paulk'. Under a typical fungicide schedule, low levels of infection with bitter rot [Greeneria uvicola (Berk. \& Curt.) Punithalingam, syn. Melanconium fuligineum (Scribner \& Viala) Cav.] and ripe rot [Glomerella cingulata (Stonem.) Spauld. \& Schrenk] were observed. Infection levels were higher than the other black cultivars 'Supreme' and 'Lane', but better than the bronze cultivars 'Fry' and 'Hall' (Table 3 ).

Muscadine grape cultivars can have either hermaphroditic or female flowers. Most commercial vineyards have large acreages of female cultivars with hermaphroditic cultivars as pollinizers. Despite the reduced productivity of most female cultivars, growers have continued to grow them because of their large berry size and better quality (Conner, 2009). The larger berry size of female cultivars is not due to lower productivity, but may be due to metaxenia or from a gene linkage (Williams, 1957). Generally, growers want a berry size of at least $10 \mathrm{~g}$ in a fresh-market cultivar. However, very large muscadines $(\approx 15 \mathrm{~g})$ can be marketed loose in cardboard boxes rather than clamshells and will bring a premium price in some markets. This is in part why the very large sized cultivar Supreme has become the most important freshmarket cultivar in south Georgia. 'Paulk' is recommended as an hermaphroditic replacement for 'Supreme'. Being hermaphroditic, 'Paulk' can serve as a pollinizer for existing 'Supreme' plantings and will have more consistent cropping than most female cultivars. Berry size and appearance of 'Paulk' is similar to 'Supreme' (Fig. 3) and should be able to substitute for 'Supreme' in most applications. 'Paulk' is superior to 'Supreme' because it has less incidence of pedicel scar tearing and splitting (Table 3). 'Paulk' tends to ripen more consistently than 'Supreme', which prevents the picking of early ripening berries for early-season sales as is often done with 'Supreme', thus growers will need to have another cultivar, such as 'Supreme' or 'Lane' for early-season sales. Given the large berry size and high production potential of 'Paulk', growers may need to limit vine fruitfulness by increasing the distance between fruiting spurs or thinning the crop so that the vine is not weakened by maturing 


\begin{tabular}{|c|c|c|c|c|c|c|c|c|c|c|c|}
\hline Cultivar & $\begin{array}{c}\text { Flower } \\
\text { type }^{z}\end{array}$ & $\begin{array}{l}\text { Berry } \\
\text { color }\end{array}$ & $\begin{array}{l}\text { Avg d of } \\
\text { first harvest }\end{array}$ & $\begin{array}{c}\text { Percent } \\
\text { berry } \operatorname{rot}^{\mathrm{y}}\end{array}$ & $\begin{array}{l}\text { Percent pedicel } \\
\text { scar split }^{\mathrm{x}}\end{array}$ & $\begin{array}{l}\text { Percent pedicel } \\
\text { scar tear }^{\mathrm{w}}\end{array}$ & $\begin{array}{l}\text { Percent dry } \\
\text { pedicel scar }^{v}\end{array}$ & Berry wt (g) & $\begin{array}{c}\text { Berry } \\
\text { diam }(\mathrm{mm})\end{array}$ & $\begin{array}{c}\text { Berry } \\
\text { seed no. }\end{array}$ & $\begin{array}{c}\text { Percent soluble } \\
\text { solids of all } \\
\text { harvests }\end{array}$ \\
\hline Paulk & $\mathrm{H}$ & Black & 20 Aug. $a^{t}$ & $8 \mathrm{~b}$ & $4 \mathrm{c}$ & $11 \mathrm{~d}$ & $85 \mathrm{ab}$ & $15.5 \mathrm{a}$ & $30.2 \mathrm{a}$ & 2.9 & 14.2 \\
\hline Fry & $\mathrm{F}$ & Bronze & 16 Aug. b & $16 \mathrm{a}$ & $18 \mathrm{a}$ & $34 \mathrm{a}$ & $48 \mathrm{~d}$ & $11.7 \mathrm{~b}$ & $27.4 \mathrm{~b}$ & 2.4 & 14.0 \\
\hline Lane & $\mathrm{H}$ & Black & 3 Aug. c & $4 \mathrm{c}$ & $22 \mathrm{a}$ & $23 \mathrm{c}$ & $55 \mathrm{c}$ & $9.6 \mathrm{~d}$ & $25.6 \mathrm{~d}$ & 2.8 & 15.3 \\
\hline Supreme & $\mathrm{F}$ & Black & 18 Aug. ab & $4 \mathrm{c}$ & $13 \mathrm{~b}$ & $29 \mathrm{~b}$ & $59 \mathrm{c}$ & $15.1 \mathrm{a}$ & $29.9 \mathrm{a}$ & 2.5 & 14.3 \\
\hline Tara & $\mathrm{H}$ & Bronze & 4 Aug. c & $10 \mathrm{~b}$ & $5 \mathrm{c}$ & $12 \mathrm{~d}$ & $83 \mathrm{~b}$ & $10.8 \mathrm{bc}$ & $26.4 \mathrm{c}$ & 2.9 & 13.9 \\
\hline
\end{tabular}

${ }^{\mathrm{z}} \mathrm{F}=$ female; $\mathrm{H}=$ hermaphrodite

${ }^{\mathrm{y}}$ Percentage of berries with visible signs of decay or fungal pathogens.

${ }^{\mathrm{x}}$ Percentage of berries which split open at the pedicel scar.

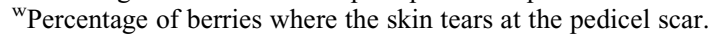

${ }^{\mathrm{v}}$ Percentage of berries with no splitting or tearing at the pedicel scar after picking.

"Seed number was only determined in 2015 and 2016.

${ }^{\text {t} M e a n ~ s e p a r a t i o n ~ w i t h i n ~ c o l u m n s ~ b y ~ D u n c a n ' s ~ m u l t i p l e ~ r a n g e ~ t e s t, ~} P<0.05$, with $n=4$.

NS = nonsignifcant.

Table 4. Change in firmness $\left(\mathrm{g} \cdot \mathrm{mm}^{-1}\right)$ of 'Paulk' and test cultivars at harvest and after cold storage $\left(0\right.$ to $1{ }^{\circ} \mathrm{C}, 90 \%$ to $95 \%$ relative humidity). ${ }^{\mathrm{t}}$

\begin{tabular}{|c|c|c|}
\hline & $\begin{array}{l}\text { Firmness } \\
\left(\mathrm{g} \cdot \mathrm{mm}^{-1}\right)^{\mathrm{y}}\end{array}$ & $\begin{array}{l}\text { Firmness } \\
\left(\mathrm{g} \cdot \mathrm{mm}^{-1}\right)^{\mathrm{y}}\end{array}$ \\
\hline Cultivar & Day 0 & $\overline{\text { Day } 10+1}$ \\
\hline Paulk & $240 \mathrm{a}$ & $203 \mathrm{c}$ \\
\hline Fry & $199 \mathrm{~b}$ & $178 \mathrm{~b}$ \\
\hline Supreme & $248 \mathrm{a}$ & $228 \mathrm{a}$ \\
\hline Significance & $<0.001$ & $<0.001$ \\
\hline
\end{tabular}

${ }^{\mathrm{z}}$ Berries were evaluated at harvest, packaged in ventilated clamshells containers, and placed in cold storage for $10 \mathrm{~d}$. Berries were then brought out of cold storage allowed to warm for $24 \mathrm{~h}$ at room temperature $\left(21^{\circ} \mathrm{C}\right)$ and evaluated $1 \mathrm{~d}$ postremoval. ${ }^{\mathrm{y}}$ Values are means with $n=4$. Each replication consisted of 25 berries measured for firmness using a Bioworks FirmTech II. Mean separation within columns by Duncan's multiple range test, $P<0.05$.

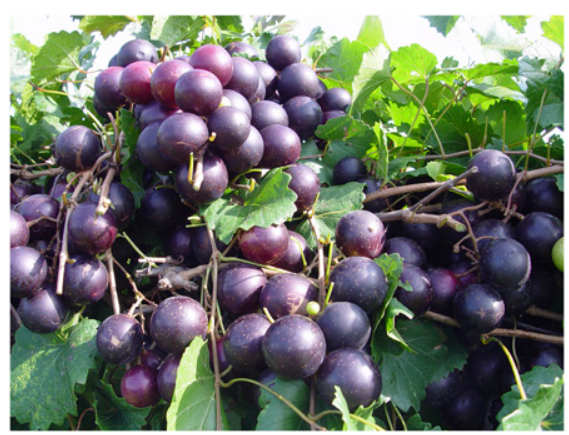

Fig. 2. Ripe berries of 'Paulk' muscadine on the vine.

excessive crops. Limited data are available to determine the cold hardiness of 'Paulk' vines,

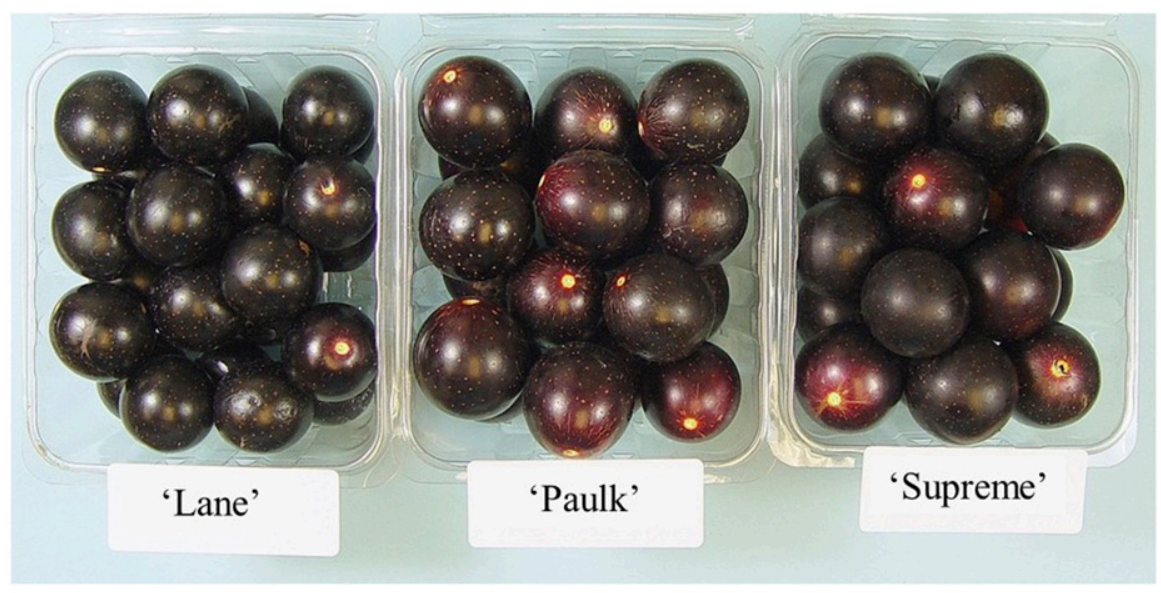

Fig. 3. Berries of 'Lane', 'Paulk', and 'Supreme' in pint clamshells.

and large plantings should not be made in the northern muscadine regions until more data are available. 'Paulk' is easily propagated by softwood cuttings rooted under mist during June and July.

\section{Availability}

'Paulk' will be a patented cultivar (USPP applied for) and is owned by the University of Georgia Research Foundation. Propagation rights are controlled by the University of Georgia Research Foundation, Technology Commercialization Office, GSRC Boyd Building, Athens, GA 30602-7411 (www. ovpr.uga.edu/tco/). A list of nurseries licensed to propagate 'Paulk' muscadine can be obtained by contacting the author.

\section{Literature Cited}

Conner, P. 2009. Performance of muscadine grape cultivars in southern Georgia. J. Amer. Pomol. Soc. 64:78-82.

Conner, P. 2013. 'Lane': An early season selffertile black muscadine grape. HortScience 48:128-129.

Conner, P. 2014. 'Hall': An early season self-fertile bronze muscadine grape. HortScience 49:688690.

Lane, R. 1993. 'Tara' muscadine grape. HortScience 28:232.

Poling, B., C. Mainland, W. Bland, B. Cline, and K. Sorenson. 2003. Muscadine grape production guide. N.C. State Expt. Serv. Bul. AG-94.

Williams, C. 1957. Relation of berry size to flower type of seedlings in muscadine grape crosses. Proc. Amer. Soc. Hort. Sci. 69:254-260. 